\title{
Accrochage in Architecture: Photographic Representations of Theo van Doesburg's
}

\section{Studios and Paintings}

\author{
MATTHIAS NOELL
}

\section{SURFACE AND SPACE}

In addition to his varied activities as a painter, theoretician, architect, critic, Dadaist and author, Theo van Doesburg was also an occasional photographer - an area of his work that has so far remained largely unknown. On the assumption that his photographs of his studios not only record changes in his private surroundings but also accompany and explain the artistic positions he was developing, the aim of this essay is to examine the surviving photographs in which Van Doesburg (but also other photographers) staged both the rooms and spaces in which he worked, in order to investigate what they reveal about his conception of modern art. ${ }^{1}$ First, however, we must acknowledge that only a few photographs from Van Doesburg's estate can be designated as the artist's own work; we must therefore conclude on their authorship by reconstruction, without being able to achieve complete certainty in this regard. Only for some of these original photographs - no glass negatives have survived - do we have positive proof: Van Doesburg's self-portrait with Nelly and camera in front of a mirror, for example, was evidently shot in Mondrian's studio at 26, rue du départ in Paris (1515 AB 9748) in 1921. ${ }^{2}$ Some of the photographic prints have inscriptions on the back: 1597 AB 9878 shows Hans Arp and Nelly in the garden of Paul Eluard; on the back, Nelly - assuming it was her noted "photo Does." Aside from a few preserved "artistic" or exper- 
imental prints, Van Doesburg produced most of his photographs for the purposes of documentation: in order to print them with his own articles or in journals, or to send them to colleagues and friends such as Piet Mondrian or people at the Bauhaus with whom he wished to discuss the progress of his art. There are entire passages in letters to friends dealing with the technical difficulties involved in reproducing colored paintings in black-and-white. ${ }^{3}$ Although an autodidact in photographic procedures, Van Doesburg was still able to think the problems through and make use of colored filters to correct the conversion of chromaticity in prints. In 1922 he explained to Evert Rinsema how to use this photographic technique: "They must use a yellow filter for the colors, otherwise the blue will come out entirely white and the yellow entirely black. If you use a yellow filter everything is correctly in balance." ${ }^{4}$ Some months later, in 1923 , he wrote to Antony Kok: "The colors have come out quite balanced in the photograph."s Van Doesburg also had a now-lost compilation of slides at his disposal, which he used for his frequent lectures - as did other colleagues with their collections, notably architects like Erich Mendelsohn or Walter Gropius. $^{6}$

In most photographs of Van Doesburg's studios of the 1920 we may observe that his paintings are not shown hanging or standing randomly in the background, but are always arranged in a close and well-balanced relationship to each other, to the visible parts of the room and its furniture, and - last but not least - to the artist himself, when he appears. By the time of the founding of the "De Stijl" movement at the latest, Van Doesburg no longer regarded the making of autonomous art as a meaningful and valuable activity. His interest was focused on the possibilities of process-related creation through art, not on art as a result of the process of creation. Showing the making of art or the circumstances under which it was made was therefore not the point; photography for Van Doesburg was not a medium to document a situation in his own life and career, but, on the contrary, was to be used to show the simultaneity of movement in time and the complex task of artwork in modern perception. Colored planes (i.e. painting), space (i.e. studio or architecture) and individual (i.e. artist) can be seen as parts of a spatiotemporal modernist game, which can be arranged experimentally in the photographic representation. We 
may describe hiding the making in order to demonstrate the impact of modern art as the essence of Van Doesburg's photographic performance and the presentation of his works of art in his photographs.

Although at the start of his career Van Doesburg still adopted the pose of the bohemian, wearing a student beret and cravat, with brush and palette, in front of his easel (1504 AB 9705), from 1917 he began to present himself in the midst of regional or "reform" furniture - two turned armchairs with a similar table - and modern arts-and-crafts objects. A double-portrait photo (fig. 1) shows Theo van Doesburg in April 1917 with Lena Milius in his studio in Kort Galgewater 3 in Leiden, where he lived for the relatively long period of three years. The painting The Card Players, still unfinished, is seen in the background, standing on Van Doesburg's easel - a group of four figures around a table. The reference to the series of the same title by Paul Cézanne (Les joueurs de cartes, around 1890/92) at first seems obvious, but the photograph in fact turns out to be a visualization of art-theoretical

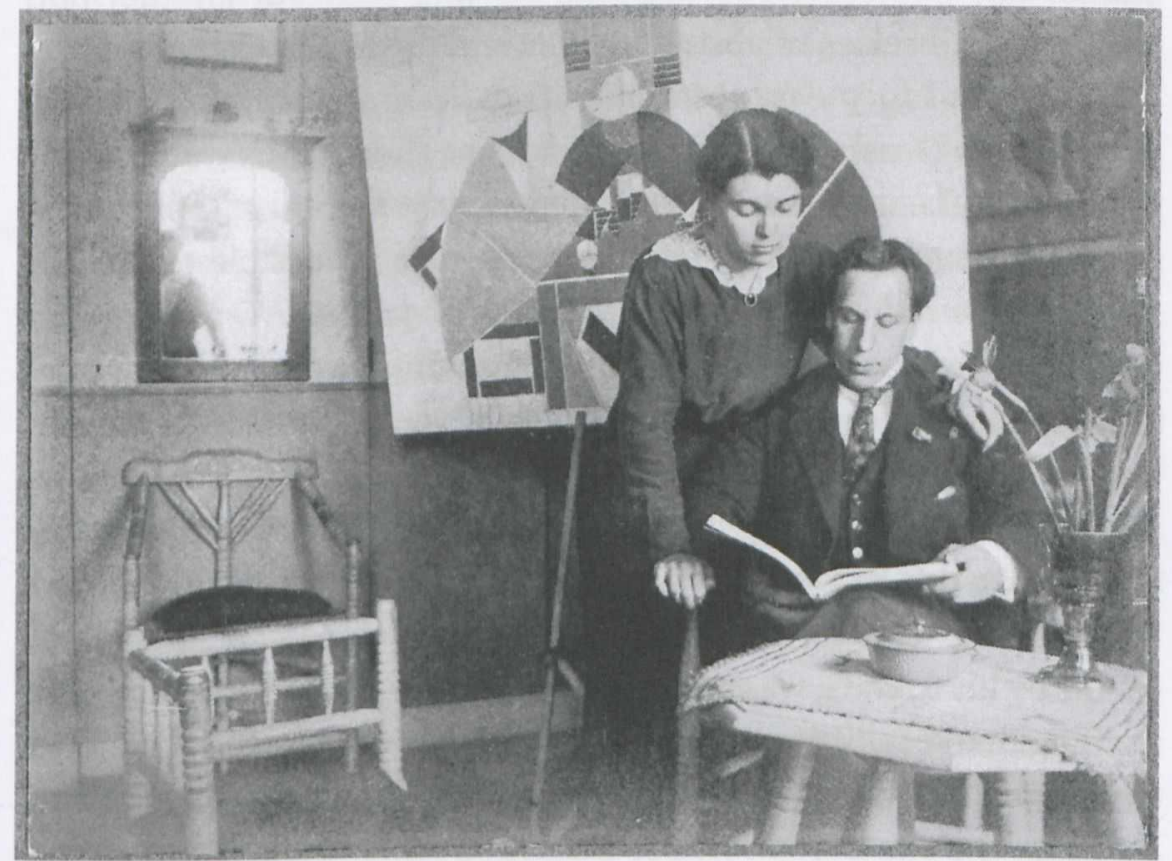

FIG. 1 Theo van Doesburg, Self-portrait with Lena Milius in the studio at Kort Galgewater 3 in Leiden, April 1917, The Hague, Netherlands Institute for Art History (RKD), The Van Doesburg Archive, inv. no. 1508 AB 9719 
ideas about ways of representing the relationship between surface and space. It is therefore only at first glance that Van Doesburg's photograph itself appears to be a domestic scene of a couple in a studio flat. In fact, the scene should be viewed as an interpretation or reduplication of the painting, which the artist has captured along with his work and an additional mirror image, reflecting Lena's back and, in the center of the mirror, an unidentified painting on the opposite wall. Van Doesburg uses the pictorial medium of photography to carry out a formal experiment in order to solve pictorial issues - the essential problem between figure and background in a painting and the way in which a flat painting affects the space with persons in front of it. Only six months later, on the basis of The Card Players and its photographic interpretation, Van Doesburg painted Composition IX - a much more abstract, "reconstructed" version of the image, although the four figures from the first picture are still recognizable. ${ }^{7}$ In a photograph from the same period we see a woman, Miss J. Th. M. Schoondergang, sitting in front of an abstract portrait, Composition XIII: Woman in the Studio. The photograph formed the starting-point for another portrait and for a series of abstract works leading to the Composition in Dissonances of 1919 - an abstract portrait in front of another abstract portrait. Van Doesburg staged another scene shortly afterwards. In the photograph, Lena Milius is seen seated directly in front of Composition XVIII (Autumn red), an abstract landscape. It is possible to identify amongst the paintings Van Doesburg's Composition $X$, Composition $X I I$, as well as an unidentified work and an unknown and remarkable piece of De Stijl furniture, probably a wooden stool or side table.

Van Doesburg arrived in Weimar in April 1921, and from July 1922 until the end of that year he rented a studio at Am Schanzengraben 8, today An der Falkenburg 3. This sparsely furnished studio, known only through a single photograph (1566 AB 10066) and some statements by his friends, was painted completely white. The photo shows nothing that recalls the artist's creative process - no easel, no palettes or brushes, and no model. In the middle of the room and in the very center of the photograph we see a drawing table with four rolls of paper, a letter balance, and a plotting board with a sheet of paper on it - we know that Van Doesburg frequently used tracing paper to copy, develop and abstract his compositions. The back of a stretcher frame 
or painting and two stained glass compositions lean against the wall, with only two abstract works hung. The huge sketch for a stained glass window may be read as a reference to the exaggeratedly dramatized, neutrally glazed, large-format studio window. Van Doesburg traced over some of the iron bars and introduced new ones in the positive photograph - altering the distribution of the bars to make it resemble the De Stijl aesthetic. He posed directly in front of the abstract dancers in Composition in Grey (Rag-Time) of 1919, a similar situation to that in his photograph in front of the Card Players. Rather than a De Stijl publication, he is holding a volume of Lajos Kassák's Hungarian avant-garde journal $M a$-most probably the current issue published in the same year, 1922 - thereby aligning himself with a very specific aspect of the Constructivist avant-garde. This particular issue included not only the famous manifesto "Bildarchitektur" (architecture of the image), but also Kassák's theory of flat painting developing into the space - a direct analogy to the ideas of Van Doesburg and designed to propagate against Walter Gropius at the Bauhaus in Weimar. On his right we see Nelly van Moorsel sitting in an armchair, on his left the philosopher Harry Scheibe reading another journal or book; several other publications lie on an additional table in the right corner.

Van Doesburg photographed himself and his friends not only in front of his paintings in his studio and in domestic situations, but also in front of urban settings that could be described as accidental ready-mades. A picture taken during an outing with his wife Nelly, his dog Dada and their friend Antony Kok along the Loire shows the three posing against the background of a rusticated façade (1589 AB 9850). Upright and horizontal rectangular fields form a background that is surprisingly similar to Van Doesburg's painted compositions dating from 1919 - first and foremost Composition in Dissonances, the "double portrait abstraction" of Miss Schoondergang sitting in front of Composition XIII: Woman in Studio.

Up to this point, most of Van Doesburg's paintings emerged from abstract depictions of human figures in a progressive evolution. His photographs trace this developmental process, form its starting point, or experiment with the effects of the paintings in space-sometimes ironically treated, as in his holiday snapshot with Nelly and Antony Kok in front of a kind of "naturally abstract" architecture. 
In the photographs of the studio in Leiden, Theo van Doesburg only touched on the question of two-dimensional surface and space - the mirror was a central theme of his visual experiments in this period. ${ }^{8}$ With the interleaving image planes - consisting of photographed three-dimensional (sculptural or architectonic) parts, and painted as well as mirrored two-dimensional parts - Van Doesburg expanded and challenged the subject of his paintings and experimented with their solution in order to advance the question of modern abstract art.

From about 1926, Van Doesburg began to move on: he now also used the method of negative montage in his photographs. His self-portrait in the studio he rented in the Villa Corot (2 rue d'Arceuil) in Paris (July 1928-December 1930) - a small, shabby complex of half-timbered buildings that still exists today - shows him working on his painting Peinture pure, which at that point had actually already been finished for eight years (1544 AB 9978). The artist's blurred outline indicates that the paper was moved during the exposure of the second negative, while the already exposed background appears mostly stable. In addition to the aforementioned topics, Van Doesburg now expanded his interest into the issue of movement in space-defined by the planes of his canvases. No later than 1923, the year of his important exhibition at the Galerie Rosenberg in Paris, the artist began to conceive of a new kind of architectural space, built up by moving bodies in time. This concept referred to the hyperspace-philosophy of the mathematician Charles Howard Hinton and the architect and theosophist Claude Bragdon. ${ }^{9}$ It was especially Hinton's idea of the hypercube, the "tesseract," that inspired Van Doesburg's own translation into architectonic-sculptural projects. A principal element was the realization of a four-dimensional space, which Van Doesburg sought to achieve by defining all the surfaces of his drawn architecture by colored planes.

A small series of photographs with double exposures and montage was especially significant for the development of this spatial concept, as it is only in these pictures that it becomes clear that the artist conceived his spaces not as mere pieces of art, but viewed the presence of moving spectators as a constitutive element. The painting Con- 
tra-Composition XVI plays a special role in this series. The photographic self-portrait with a blurred Dada might initially be seen as a simple snapshot, with the dog apparently having moved during the exposure, but other similar pictures in front of the same Contra-composition indicate Van Doesburg's deeper interest in the interaction of fore- and background, of artwork and human being. A multiple-exposure photograph published in De Stijl by Van Doesburg himself in 1926 shows that the large-format painting once again formed more than merely an accidental backdrop in the studio. In 1925, Theo van Doesburg photographed two professional dancers in front of the vertically positioned Contra-Composition XVI. In the case of the Russian choreographer, musician, author and dancer Valentin Parnac (Parnakh), Van Doesburg attempted to realize a stable photograph of the dancer in front of the canvas, which he used two times for the print. In one of the two surviving prints (1684 AB 10236), Parnac appears in front of the painting, which has been positioned behind him. In the other, a second exposure of the painting has also been superimposed on top of him. Here, movement in space, architecture and the painting correlate and mutually determine one another. Van Doesburg uses the artificial technique of double exposure as an alternative to the mirrors, with their reflecting spatial layers. The painting Contra-Composition $X V I$ seen in the photograph is in turn also closely linked to the model for the Aubette dance-hall in Strasbourg (1926-28), in which the dancers moved in front of and within a spatial painting, with a row of mirrors reduplicating the scenery on one wall.

The multiple exposure of Nelly van Moorsel that Van Doesburg made in 1926 shows another context for these ideas (fig. 2). On the back of the photograph he wrote the following, in somewhat awkward German: "Simultan Porträt von Nelly-Pétro, und die Hunde u Kätze" ("Simultaneous portrait of Nelly, with dogs a[nd] cats); and again: "Aufnahme Théo van Doesburg 1926" ("Photograph by Theo van Doesburg"). It is a very sophisticated composition showing a small Nelly sitting cross-legged within the black bar at the left edge of the canvas in Contra-Composition VIII. At the same time, Pétro - the alter ego of Nelly, whose full first name was Petronella - sits in front of the painting in the studio with two or more animals. Van Doesburg may have used several negatives for this print, as we see some "flying" 


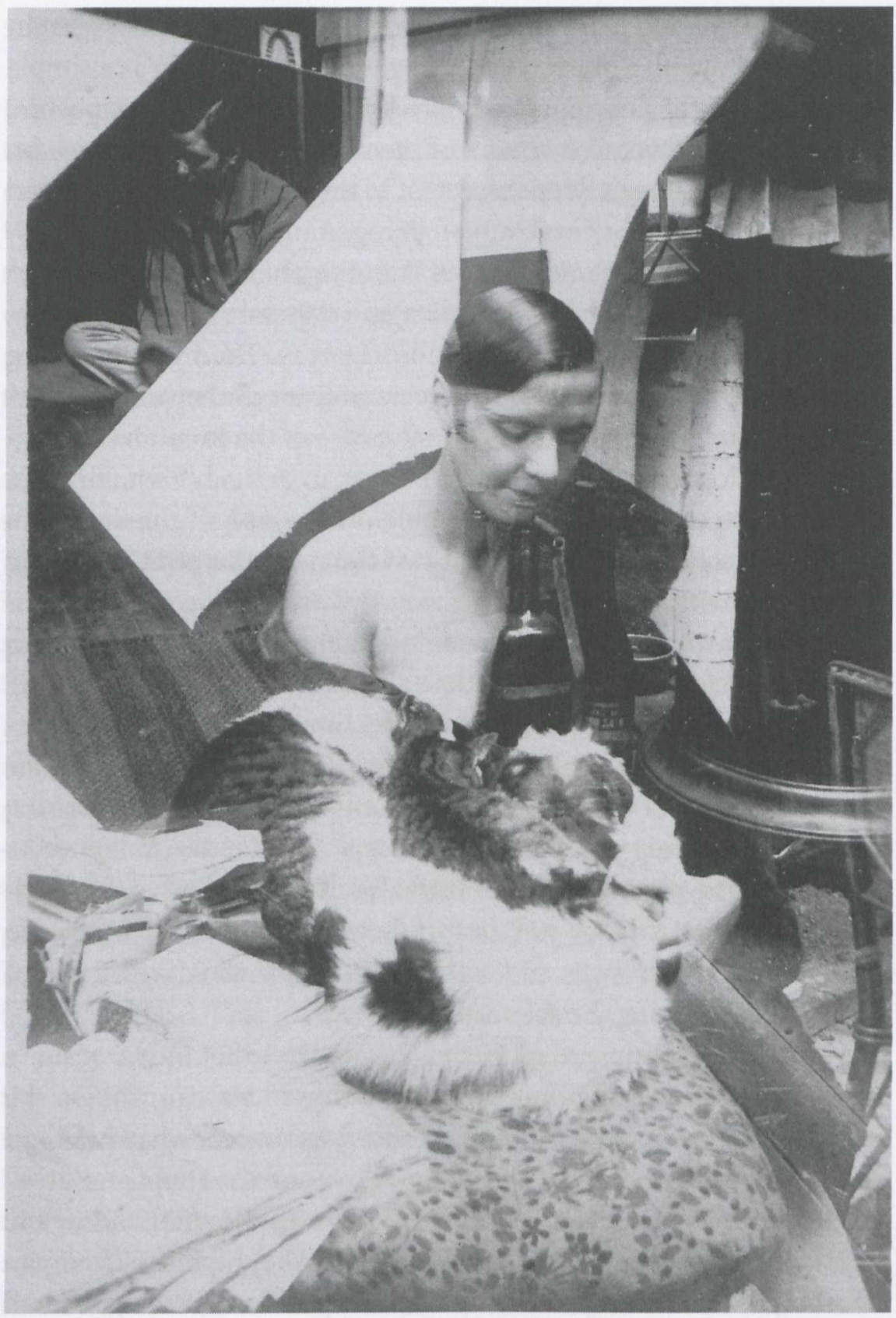

FIG. 2 Theo van Doesburg, double-portrait of Nelly van Moorsel in the studio in Clamart (64, avenue Schneider), 1926, The Hague, Netherlands Institute for Art History (RKD), The Van Doesburg Archive, inv. no. 1535 AB 9921 
bottles and glasses and a round table that do not jive very well with the other planes.

This photograph was published as an illustration to an article by Hans Möhring, in which the German graphic designer reviewed modern graphic-design solutions. Möhring discusses a (now probably lost) poster by Van Doesburg $(80 \times 55 \mathrm{~cm})$ that used the photo with Nelly-Pétro. This poster was an advertisement for the artist's own play of the meaningful title La double vision, which he had published under the pseudonym of I.K. Bonset as Het andere gezicht. Abstracte, sur-humanistische roman (The Other View. An Abstract Sur-humanistic Novel). ${ }^{10}$ Möhring writes:

Only by means of photography - including the techniques of developing and copying - can a dramatic event be represented and used effectively as propaganda; its intensity tells the people of today all the more in the measure that it recognizes and experiences all appearances and all time-bound events. ${ }^{11}$

We do not know if the play was actually performed, nor if Nelly was involved in it, but the photograph seems to have been a perfect visualization of the content: the title - "Double vision" - could be interpreted as the simultaneous perception of two images of a single object or person, as in the photograph; but also as an unconscious - "superhuman" - apparition.

This second interpretation leads to another photograph, already mentioned, with Nelly and Hans Arp (1597 AB 9878). The double exposure shows the nearly completely bleached-out portrait of Nelly and, implanted in her head, a superimposed Hans Arp, seated at a table in the garden of Paul Eluard. ${ }^{12}$ "Ensemble inseparables," Eluard wrote in a poem of the same period. ${ }^{13}$ And, on another photograph (AB 10210) depicting an unknown woman and two superimposed portraits of Frederick Kiesler, Van Doesburg wrote: "Kiesler umarmt von dieser jungen Dame verdoppelt sich" ("Kiesler, embraced by this young woman, duplicates himself.")

Such superimpositions were not restricted to photography: Van Doesburg used the same strategy in the field of typography - with letters printed in two sizes and colors layered one upon the other, or 
text laid over photographs. He had already begun experimenting with overlapping typographic elements in 1920 , for example for the cover of his book Klassiek-Barok-Modern. ${ }^{14}$ A well-known example of the procedure of combining photographs and typography is the cover of the anniversary issue of De Stijl, from 1927, in which Van Doesburg printed quotes from friends and critics about the journal over his own portrait. The original exposure (1543 AB $9972 \mathrm{~B}$ ) shows him in front of Contra-Composition XIII of 1925/1926 - shot in his studio. ${ }^{15}$

Van Doesburg found his way back to painting in the course of 1929. He translated his superimpositions, double exposures and simultaneous portraits into so-called "Simultaneous Compositions" and "Simultaneous Contra-Compositions," with their two systems of color planes and black bars separated from one another but overlapping, like the two negatives in the photographic prints.

\section{ACCROCHAGE IN ARCHITECTURE: MEUDON}

In December 1930, the Van Doesburgs moved into a studio-house in Meudon, which Theo had designed for himself. For the first time, he now had an opportunity to conceive, produce and present his paintings not in pre-existing rooms, but in a building he had designed specifically for the purpose. In a period of just under two months, between his move into the new building and his death, Van Doesburg himself most probably hung his paintings or placed them on picture-rails, installed lamps, and furnished the studio.

Before and shortly after the building and the interior decoration were finished, Van Doesburg made a small series of photographs of both the exterior and the interior. These are characterized by the use of a focal length not short enough for normal architectural photography and by an original focus on the object - thus simultaneously unprofessional in a conventional sense and precise in the choice of the motif. Some of them have been retouched to hide the technical additions to the house or things lying in the foreground (for example 1391 $A B$ 9637). Amongst these are at least three marked with details for publishing (for example $1391 \mathrm{AB} 9639 \mathrm{~A}$ ), but none of them appeared after Van Doesburg's death. ${ }^{16}$ Only two of the series, both with nor- 
mal retouches, were printed in Abraham Elzas's article for the last issue of De Stijl, which appeared in January 1931; these show only the more general views of the building. All our remarks make it plausible that Van Doesburg was the sole author of this particular photographic series and their additional markings.

We also know of a few pictures taken by the Société Solomite, the company responsible for the building's construction, who undoubtedly hoped to gain new customers by publishing pictures of the construction process and the finished modern dwelling. The Van Doesburg Archive contains some of these photographs and of other buildings realized by the Société Solomite (like 1388 АВ 9617).

Probably before August 1935 - when they were published in another article by Abraham Elzas - Nelly commissioned yet another series of photographs, showing the studio with Van Doesburg's paintings on the wall (1393 and $1392 \mathrm{AB} 9658) .{ }^{17}$ In one of these, a plaster mask perhaps Van Doesburg's death mask - appears on the wall between the windows. Five small prints (1393 AB 9660), stuck together on a sheet of black cardboard, show the same hanging, but in a more cluttered studio, with a provisional drawing table with drawing paper and a T-square lying on it - most probably Theo's rather than Nelly's tools.

We have to conclude, then, that the interior of the studio-house was most probably completed before Van Doesburg died in March 1931. Between 24 February and 7 March 1931, the day of his death, Nelly and Theo van Doesburg were in Davos, due to his grave illness. Some weeks later - Nelly had still not returned to France-Alexander Dorner visited the house in Meudon with their neighbor and friend Hans Arp. On this occasion, the director of the Provinzialmuseum in Hanover chose a painting for his collection, Simultaneous Composition $X X I V$. He described it in a letter to Nelly as the one "[...] hanging in the studio by the stairs leading to the roof terrace." ${ }^{18}$ We must therefore consider the hanging of Van Doesburg's paintings as his own work, even if Simultaneous Contra-Composition, seen in an orthogonal photograph of the east wall at top of the metal staircase, was sent to Antony Kok after an exhibition in Barcelona in January 1930 and was only officially reacquired by Nelly some years later. But, as in the case of Contra-Composition XX, sold to Otto Carlsund after the same exhibition and quickly returned the same year, it is difficult to inter- 
pret the presence of this canvas in his studio. Van Doesburg had sold both of the works seen in the photograph, and he wrote to Kok that he could easily exchange it for another of his paintings. ${ }^{19}$

The three aforementioned and larger photographs - one of which is not preserved as a print in the Van Doesburg Archive, but published in a volume of De 8 en Opbouw - depict different walls of the studio and thus respond to the specific situation of Van Doesburg's works shown; these in turn appear to explain the architecture of the studio and of the building as a whole. Three different angles have been chosen for the three details, and the resulting surface composition is rendered legible in the process by analogy to the paintings. The building's diagonal, vertical and horizontal lines are carefully balanced with those of the paintings, creating a dialogue in the photograph between the building, the art and the way in which it is hung.

The first photograph was shot nearly orthogonally to the east wall. The architectural elements of the gallery, with its railings, the iron staircase and the concrete-built stairwell to the ground floor, reflect on the one hand the orthogonal pictorial structure of Peinture pure, seen in the lower right corner of the photograph, and, on the other, the diagonals of Contra-Composition V (1924) and Simultaneous Contra-Composition (1929). Van Doesburg's "Simultaneous compositions" emerged from the superimposition of two independent levels of painting: the colored surfaces and a scaffolding of black lines. The railing can therefore be read as a counterpart to the "Simultaneous compositions" on the wall, which are extended into the space of the room through these references.

The second photograph, which was taken at an oblique angle looking down from the gallery into the room, shows a compositional principle that contrasts with that of the first. The distribution of the furniture on the floor surface initially corresponds to the right-angled surfaces of Composition XX on the wall. However, following the compositional principles of Van Doesburg's "Elementarism" (consisting mainly of inclined surfaces, disequilibrium, tension, and dissonance of colors) - and Contra-Composition VIII in particular is a key work here - the photograph shows an arrangement of surfaces lying at right angles to each other within a diagonal view of the room. While the alignment of the swing-arm lamp (a design by Bernard Albin Gras 
from the beginning of the 1920s) is subordinated to the lines of Contra-Composition VIII, the shadowed empty space of the floor, the window sill and the niche appear to translate the two black bars in the painting onto the photographic surface. Thus, while the works from the Composition-series in both photographs form an analogy with the arrangement of the paintings and furniture on a surface, the task assigned to Contra-Compositions and Simultaneous Compositions is to structure the space.

The third photograph, a diagonal view of the south wall of the studio, cuts into both the stairwell and the gallery, as well as into the west wall, and shows the studio door opening onto the hallway. Here we see numerous paintings standing on three wooden ledges, gathering together Van Doesburg's most recent paintings from 1929 and 1930, but accompanied by a whole series of older sketches.

Through the way in which he hung Arithmetic Composition (1930), Theo van Doesburg sought to elucidate the analogy between architecture and painting. The building, with its two diagonally superimposed rectangles, developed from a quite comparable shifting of a quadratic surface through space. This becomes particularly clear in the way in which the building's black and white axonometry is juxtaposed with Arithmetic Composition. Van Doesburg had already published a sequence of six preliminary stages for the painting in the German journal Die Form in 1929. The caption to the illustration reads: "Von der Fläche zum Raum. Sechs Momente einer raumzeitlichen Konstruktion (mit 24 Variationen). Gestaltung schräger Dimension." 20

Abraham Elzas, the young Dutch architect and Van Doesburg's short-term assistant who most likely drew the axonometry for him, understood this context and published the painting together with the axonometry in an article in De 8 en opbouw in 1935. This comparison also makes particularly clear the close link between Van Doesburg's architectural work and the Art concret group, inaugurated in 1930, with their principles of precisely calculated and mechanically executed, "non-accidental" art. Against this background, the diagonal arrangement of the two blocks of the house can also be described as the progression of a quadratic surface through space in an oblique dimension. However, thanks to the way in which it is hung on the central axis of the studio door, Rhythm of a Russian Dance can also be related 


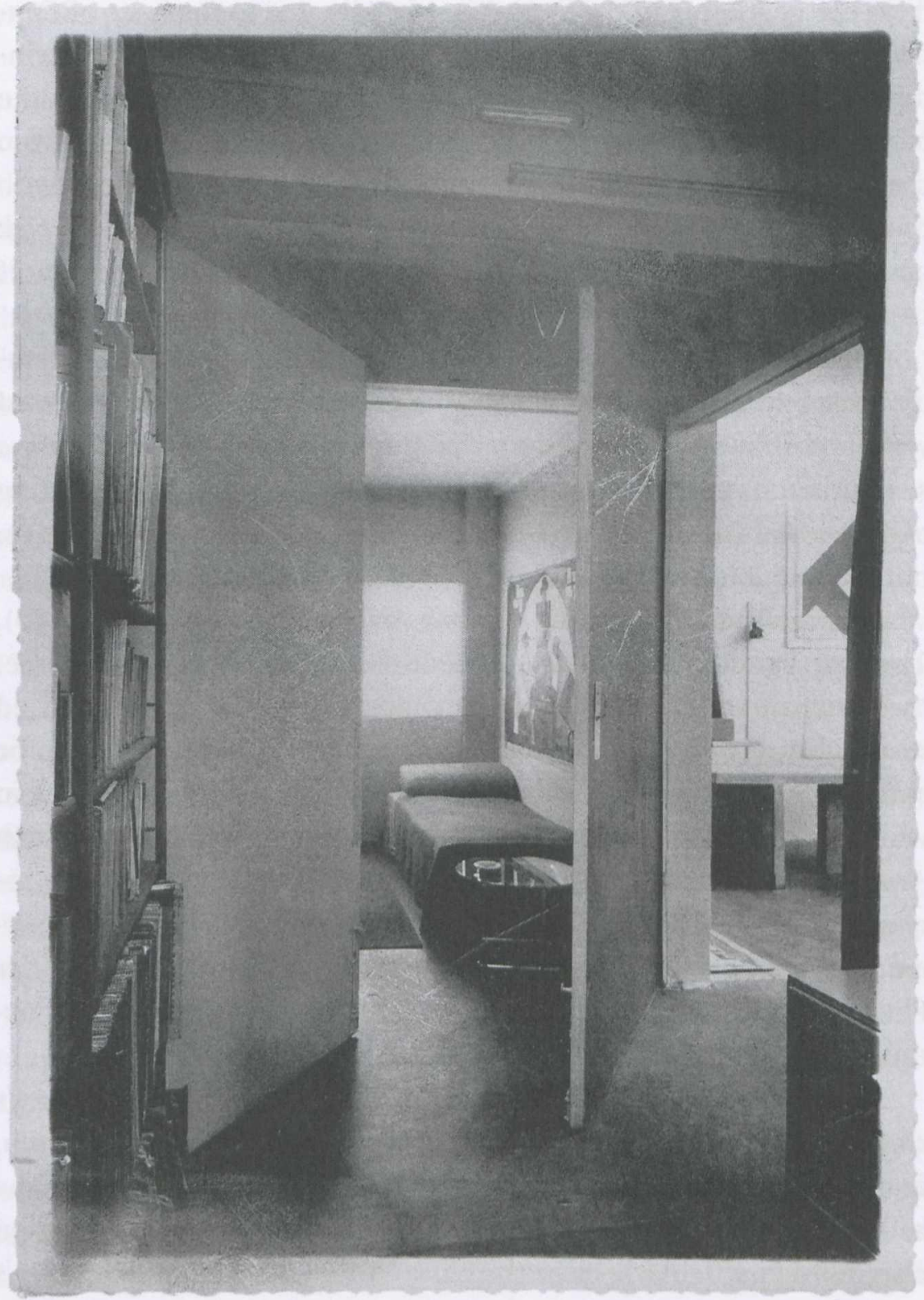

FIG. 3 Theo van Doesburg, view from the library into the music room and the studio in Meudon (41, rue Charles Infroit), 1931, The Hague, Netherlands Institute for Art History (RKD), The Van Doesburg Archive, inv. no. 1392 AB 9659 
directly to the building's architecture and in particular to its rotating doors. Each movement of the ceiling-high doors alters the relationship between front and back, interior and exterior, room and intermediate room, human being and space. However, for people within the rooms, the alignment of the space itself also changes with the doors.

The close relationship of the paintings to the real architectural situation in Meudon becomes even clearer through a direct comparison of the painting Interieur with another photograph of the building (fig. 3). A view from the library into the hallway, music room and studio is provided when the rotating doors are opened diagonally into the space - that is, half-open, half-closed. Architecture, the photographic representation of the architectural space, and the paintings go hand in hand here. For a short time - presumably only for this one photograph - Van Doesburg rotated Contra-Composition VIII by 45 degrees, so that its diagonal appears to respond to the diagonal bar on the right edge of the painting. ${ }^{21}$ Showing the broader context of Van Doesburg's creative process in each individual painting, as well as explaining the development of a concrete artistic language ("peinture concrète et non abstraite" ${ }_{22}$ ), the arrangement of the works leads furthermore to a more precise perception and reading of architectural, Euclidean space, and to Van Doesburg's own creation of a fourdimensional space. The three photographs of his studio also create a kind of "retrospective" of his work, adding an additional layer of creation.

\section{STUDIO AND PAINTING - ARCHITECTURE AND COLOR}

The compilation and consolidation of many years of experimentation in the form of his studio residence for the first time brought actually built architecture within the orbit of Van Doesburg's theory. The rotation of spatial alignment is given a conceptual counterpart in external space as well. In his triple axonometry, he transferred the concept of the simultaneity of space and time from painting and photography to the graphic medium of representation that he had introduced into modern architecture together with Cornelis van Eesteren in 1923. It was this concept's dissolution of the viewer's perspective that first 
made possible a rotation on one and the same ground plan. The superimposition of the three axonometries dissolves spatial boundaries that were previously firmly defined and leads to a dissolution of form in favor of a purely temporal presence of space. The figure of Valentin Parnac, dancing through the various layers of Contra-Composition $X V I$, is therefore comparable to the rotating interior space of the studio residence. The barely legible axonometry and sketch for the 1923 Maison d'artiste, which is itself the first sketch plan for his own studio residence, mutually explain their own origins. While in the older, conceptual sketch, Van Doesburg was actually attempting to develop mobile space in every direction, the later and ultimately practicable design for Meudon freezes the space into a single state. However, it continues to move along with its user in the interior.

On closer comparison of interior and exterior, however, an unsolvable problem emerges. If the movable door surfaces on the white exterior are kept in what Van Doesburg called the active primary colors - thereby attesting to the role that Van Doesburg assigned to color in a four-dimensional design - the studio is reduced to the "passive" color-shades of white, black and grey. Just as Van Doesburg's ten-year effort to unite painting and architecture failed, so too did the studio in achieving this goal. In the year in which the building was completed, his work on the studio and in architecture led to the manifesto of Concrete Art - to an autonomous art independent of architecture. In Van Doesburg's words, creation is a result of the intellect, not a work of the hand, emotion or sensitivity: "The evolution of painting is nothing but the intellectual search for truth through the culture of the optical." ${ }_{23}$ This almost inevitable development is inscribed into the photographs of his first and last self-designed studio. Van Doesburg's accrochage eliminates the making of his art, but it shows the development and progress of his radical conception of "the clarity that will form the basis of a new culture." 24

NOTES

1 Only a few historians refer to Van Doesburg's photographic work as an artistic statement or experiment: Herta Wescher, Die Collage. Geschichte eines künstlerischen 
Ausdrucksmittels (Cologne: DuMont Schauberg, 1968), 159-160, ill. 263; Erika Billeter, Malerei und Photographie im Dialog von 1840 bis heute (Bern: Benteli, 1977), 274-303, mainly 290, ill. 682, and 304-319; Kees Broos and Flip Bool, De Nieuwe Fotografie in Nederland (The Hague: Fragment, 1989), 15 and 42; Mattie Boom and Janine Dudok van Heel, "Theo van Doesburg," Geschiedenis van de Nederlandse fotografie 1/21 (1993) 1-13, ill. A-f (loose-leaf collection). On experimental photography in general, see for example Klaus von Beyme, Das Zeitalter der Avantgarden. Kunst und Gesellschaft 19051955 (Munich: Beck, 2005), 472-492. For general information on Theo van Doesburg see Els Hoek et al. (eds.), Theo van Doesburg. œuvre catalogue (Otterlo: Centraal Museum Utrecht and Kröller-Müller Museum Otterlo, 2000); Joost Baljeu, Theo van Doesburg (London: Studio Vista, 1974); Allan Doig, Theo van Doesburg. Painting into Architecture, Theory into Practice (Cambridge: Cambridge University Press, 1986); Evert van Straaten, Theo van Doesburg. Painter and Architect (The Hague: SDU, 1988); Sjarel Ex, Theo van Doesburg en het Bauhaus. De invloed van De Stijl in Duitsland en Midden-Europa (Utrecht: Centraal Museum, 2000); Jo-Anne Birnie Danzker (ed.), Theo van Doesburg. Maler - Architekt (Munich: Prestel, 2000). The topics of this essay are addressed in a broader context in Matthias Noell, Im Laboratorium der Moderne. Das Atelierwohnhaus von Theo van Doesburg in Meudon - Architektur zwischen Abstraktion und Rhethorik (Zurich: gta Verlag, 2011) and in Matthias Noell, "Konkrete Gesellschaft. Zum Verhältnis von Mensch, Raum und Architektur bei Theo van Doesburg, Franz W. Seiwert und Max Bill," in: Julia Friedrich, Nina Gülicher, Lynette Roth (eds.), Form und Gesellschaft (Cologne: Museum Ludwig, 2008), 31-42.

2 The Van Doesburg Archive (VDA), in the Rijksbureau voor Kunsthistorische Documentatie (RKD), The Hague, holds all of Van Doesburg's photographs.

3 Hoek et al. 2000, no. 621f: 504, letter from Theo van Doesburg to Antony Kok, 17 March 1930: "Spoedig foto's!"

4 Letter to Evert Rinsema, 19 June 1922, VDA, English translation in Hoek et al. 2000, no. 672.11: 300 .

5 Letter to Antony Kok, 6 August 1923, VDA, English translation in Hoek et al. 2000, no. 715: 371.

6 See Theo van Doesburg, "Data en feiten," De Stijl 7 79/84 (1927) 53-71, esp. 55-56.

7 The painting was referred to by Van Doesburg as a "reconstruction" of the Card Players; see Hoek et al. 2000, 206.

8 See also the photograph 1543 AB 9971.

9 Linda Dalrymple Henderson, The Fourth Dimension and Non-Euclidian Geometry in Modern Art (Princeton, NJ: Princeton University Press, 1983).

10 I.K. Bonset [= Theo van Doesburg], "Het andere gezicht. Abstracte, sur-humanistische roman. Voorwoord. Hoofdstuk 1. Hoofdstuk 2," De Stijl 7/77 (1926/27) 66-70, 505-507; see Hoek et al. 2000, no. L218: 725-726; no. L220: 727-731.

11 Hans Möhring, "Das photographische Bild im Dienste der Reklame," Offset. Buchund Werbekunst 5/11 (1928) 447-451: 451. "Nur mit den Mitteln der Photographie - einschließlich des Enfwicklungs- und Kopierverfahrens - wird ein dramatisches Geschehen 
dargestellt und propagandistisch zur Wirkung gebracht, deren Intensität sich dem heutigen Menschen umso mehr mitteilt, je stärker seine Existenz in allen Erscheinungen und allem zeitbedingten Geschehen erkennt und erlebt."

12 Van Doesburg used a negative with Hans Arp and Nelly van Moorsel in the garden (1597 AB 9877) and a second with Nelly with trees in the background. Compare a similar photograph in Hans Richter, Filmgegner von heute - Filmfreunde von morgen (Berlin: Reckendorf, 1929), also published in Die Form. Zeitschrift für gestaltende Arbeit 4/10 (1929) 251.

13 Paul Éluard, L'amour la poésie [1929], published in Capitale de la douleur, suivi de L'amour la poésie (Paris: Gallimard, 2009), 161.

14 Theo van Doesburg, Klassiek - Barok - Modern (Antwerp: De Sikkel, 1920).

15 For similar designs see: Arthur A. Cohen, Herbert Bayer. The Complete Work (Cambridge, MA/London: MIT Press, 1984), 221; Heinz Hajek-Halke, Form aus Licht und Schatten (Göttingen: Steidl 2005), 27 and 40. In general: Kees Broos, "Das kurze, aber heftige Leben des Rings 'neue werbegestalter', " Typographie kann unter Umständen Kunst sein." Ring "neue werbegestalter." Die Amsterdamer Ausstellung 1931 (Wiesbaden: Spangenberg 1990), 7-10, 8; Christine Kühn, Neues Sehen. Fotografien der Zwanziger Jahre (Berlin: SMB Kunstbibliothek, 2005), 169-170. See also László Moholy-Nagy, Malerei, Fotografie, Film (München: Langen 1925); Jan Tschichold, "fotografie und typografie," Die Form. Zeitschrift für gestaltende Arbeit 3/3 (1928) 140-150; Yvonne Brentjens, Piet Zwart. Vormingenieur (Zwolle: Waanders 2008); Dick Maan, Paul Schuitema. Beeldend organisator (Rotterdam: 010, 2006); Max Bill, Typographie, Reklame, Werbegestaltung (Sulgen/Zürich: Niggli, 1997); Max Bill, Aspekte seines Werks (Sulgen/ Zürich: Niggli, 2008).

16 See again the letter from Theo van Doesburg to Antony Kok, 17 March 1930, in Hoek et al. 2000, no. 621f, p. 504 .

17 It may have been Elzas himself who took these photos. See Abraham Elzas, "Theo van Doesburg," De 8 en opbouw 6/17 (1935), 173-184. Wies van Moorsel attributes some of the pictures to Ad Petersen, who took some photographs during the 1970 . See Wies van Moorsel, Nelly van Doesburg 1899-1975, "de doorsnee is mij niet genoeg" (Nijmegen: Sun, 2000), here cited in the German edition (Sulgen/Zürich: Niggli, 2002), 270.

18 Letter from Alexander Dorner to Nelly van Doesburg, 2 May 1931; cited in Hoek et al. 2000, 499: "[...] das i. Atelier an der Treppe zum Dachgarten hängt."

19 See the letters to Otto Carlsund in 1930 and to Antony Kok, 23 January 1930, both VDA.

20 Theo van Doesburg, "Film als reine Gestaltung," Die Form. Zeitschrift für gestaltende Arbeit 4/10 (1929) 241-249: 241. The translation is roughly: "From surface to space. Six instances of a spatio-temporal construction (with 24 variations). Formation [of a] diagonal dimension."

21 Compare Van Doesburg's photographic portrait of Branko Ve Poljanski, taken in 1925 in front of the turned Contra-Composition VIII in his studio in Clamart, published in Irina Subotic and Vida Golubovic, Zenit and the Avant-Garde of the Twenties (Belgrade: 
Narodni muzej, 1983), and in œuvre catalogue 2000, 407.

22 [Theo van Doesburg], "Commentaires sur la base de la peinture concrete," Art concret 1/2-4 (1930) 2.

23 Ibid., 3. "L'évolution de la peinture n'est que la recherche intellectuelle du vrai par la culture de l'optique."

24 Ibid., 4. "[...] clarté qui sera la base d'une nouvelle culture." 